\title{
SEXING OF HUMAN CLAVICLES OF NORTH KARNATAKA ZONE BY MEASURING THEIR MID-SHAFT CIRCUMFERENCE
}

\author{
Shobha ${ }^{1}$, Vijayakumar B Jatti ${ }^{*}$, Pravinkumar NK ${ }^{3}$, Vasudeva Murthy.CR ${ }^{4}$. \\ ${ }^{1}$ Associate Professor, Department of Anatomy, J J M Medical College, Davangere, Karnataka. \\ India. \\ ${ }^{* 2}$ Professor and Head, Department of Forensic Medicine, S. S. I. M. S. \& R. C., Davangere. Karnataka, \\ India.
}

${ }^{3}$ Associate Professor, Department of Forensic Medicine, S. S. I. M. S. \& R. C., Davangere. Karnataka.

${ }^{4}$ Senior lecturer, Department of pathology, International medical university, Kuala Lumpur, Malaysia.

\section{ABSTRACT}

\begin{abstract}
The sex determination of the individual is primary criterion of identification in Forensic anthropology but this is very difficult problems $\&$ becomes even more challenging when only a single bone like clavicle is available. The correct determination of the sex of a dead person is a critical requirement in physical anthropology. Within past few years, the physical anthropologists have become increasingly involved in the problems of human identification. The traditional methods of sexing bone are subjective and not of much help where $100 \%$ accuracy of sexing is required. For the metrical analysis of sexing of clavicle by the present study method, mid-shaft circumference of 155 adult human clavicles of known sexes were measured with the help of measuring tape, strip of graph paper and Vernier Calipers. The mid-shaft circumference of right side male clavicles ranges from $30 \mathrm{~mm}$ to $46 \mathrm{~mm}$ (mean of $37.14 \pm 4.10 \mathrm{~mm}$ ), where as that of female clavicles ranges from $25.5 \mathrm{~mm}$ to $41.5 \mathrm{~mm}$ (mean of $30.50 \pm 3.3 \mathrm{~mm}$ ). The mid-shaft circumference of left male clavicles ranges from $30 \mathrm{~mm}$ to $48 \mathrm{~mm}$ (mean of $37.04 \pm$ $4.2 \mathrm{~mm}$ ) where as that of female clavicles ranges from $24.5 \mathrm{~mm}$ to $39.5 \mathrm{~mm}$ (mean of $30.3 \pm 3.3 \mathrm{~mm}$ ). The mid-shaft circumference of clavicles has a high significance in sex determination $(P<0.001)$. The prediction of correct sex by mid-shaft circumference of clavicles alone is $77 \%$ for male $\& 83.30 \%$ for female right clavicles $\& 80 \%$ for of male \& $87.50 \%$ for female left clavicles.
\end{abstract}

KEY WORDS: Anthrolopology, Human Identification, Morphometry, Skeletal Remains, Mid-Shaft Circumference.

Address for Correspondence: Dr. Vijayakumar B Jatti, Prof. and Head, Dept of Forensic Medicine, S. S. I. M. S. \& R. C., Davangere. Karnataka, India. Mob: 09886740714. E-Mail: drvbjthanu@gmail.com

Access this Article online

Quick Response code

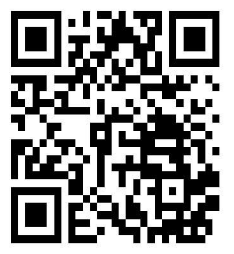

DOI: $10.16965 /$ ijar.2018.420

Journal Information

International Journal of Anatomy and Research

ICV for 2016 ISSN (E) 2321-4287 | ISSN (P) 2321-8967

90.30

https://www.ijmhr.org/ijar.htm

DOI-Prefix: https://dx.doi.org/10.16965/ijar

Article Information

Received: 09 Nov 2018

Peer Review: 11 Nov 2018

Revised: None
Accepted: 14 Dec 2018

Published (O): 05 Jan 2019

Published (P): 05 Jan 2019

\section{INTRODUCTION}

Determination of the Sex is an important and essential step towards establishing identity of unknown human from skeletal remains. The correct- determination of the sex of a dead person is a critical requirement in the physical anthropology. While establishing the identification of the age, sex, stature $\&$ race of the person are the primary criteria's ( bog fours) of identification, Among them the determination of the Sex is statistically the most importantcriteria as it immediately excludes approximately half of the population. As the obvious Sex differences become apparent only after puberty, the adult clavicles were chosen for the study. When a complete skeleton is available for examination it is not a difficult task to determinine the sex. However, the accuracy of 
sex assessment of the skeleton is directly proportional to the no of bones available [1-3]. Traditional methods of determining of the Sex depend on experts ability \& experiences \& show subjective variation (4 (12) D The sexing of clavicle had been attempted in western countries. By using Mid-Shaft Circumference with was good criterion 5 (13,14 D) Similar Studies have been done in India on clavicles using their MSL layer. \& weight \& found that the MSL as best criterion for identifying the sex. Even though many workers. Studying the morphometric data of the clavicles extensive at the various parts of the world. The available literature clearly show that there is pinching of metrical data of the clavicle in this geographical region. Hence the present study is undertaken with a view to study, the sexual difference in Mid-Shaft Circumference of adult human clavicles of known sex. This study is based on the measurement of Mid-Shaft Circumference of clavicles of the known sex from this region (North Karnataka) \& inter comparing their value with clavicles of unknown individual so that one can properly identify their sex \& will help to build context of reference value for the population of those geographical region.

\section{MATERIALS AND METHODS}

The total 155 dried clavicle of adult human bodies of known sex ( 85 male \& 75 females) were obtained from Anatomy departments SSIMS \& RC Davangere. JJM medical college. Davangere, S.N. Medical college, Bagalkote \& Shri B.M patil medical college, Bijapur. The present study $\mathrm{s}$ conducted at the department of Anatomy SSIMS $\& R C$. Davangere Before the measurement were taken the clavicles were cleaned $\&$ dried. Out of 85 male clavicles 39 were of right side \& 46 were of left sided. \& out of 70 female clavicles, 30 were of right sided \& 40 were of left sided.

Measurement of Mid-shaft circumference of the clavicle: While measuring the length of clavicle, a mark was done with pencil at the middle of distance between two ends of clavicle. At this midpoint, circumference was measured in millimeters $(\mathrm{mm})$ with the help of calibrated narrow strip of graph paper or a thread (fig: 1and 2).

After all the measurements \& observations these data are statistically analyzed by univariate discriminate analysis. The findings they generated are compared with previous studies by different authors (as shown in Table No: 2 )

The data was collected, analyzed \& subjected to statically analysis using statistical package for social science (SPSS) to find the relation between the Mid-shaft Circumference clavicles $\&$ to sex of the person.

The approval from the institutional ethical committee was obtained at the beginning of the study.

\section{RESULTS}

In present study the total of 155 dried \& cleaned adult human clavicles of know sex have been studied by measuring their Mid-shaft Circumference. The values of range \& mean of most of the parameter of male clavicles were higher compared to female cluster.

Table 1: Discriminant analysis of mid-shaft circumference (in $\mathrm{mm}$ ) of male and female clavicles.

\begin{tabular}{|c|c|c|c|c|c|}
\hline \multirow{2}{*}{ SI no } & Details of & \multicolumn{2}{|c|}{ Right } & \multicolumn{2}{|c|}{ Left } \\
\cline { 3 - 6 } & measurements & Males & Females & Males & Females \\
\hline 1 & No. of bones & 39 & 30 & 46 & 40 \\
\hline 2 & Range & $30-46$ & $25.5-41.5$ & $30-48$ & $24.5-39.5$ \\
\hline 3 & Mean & 37.14 & 30.5 & 37.04 & 30.3 \\
\hline 4 & SD & 4.1 & 3.3 & 4.2 & 3.3 \\
\hline 5 & p Value & \multicolumn{2}{|c|}{$\mathrm{P}<0.001 \mathrm{HS}$} & \multicolumn{2}{|c|}{$\mathrm{P}<0.001 \mathrm{HS}$} \\
\hline 6 & $\begin{array}{c}\text { Probability of } \\
\text { prediction }\end{array}$ & $77 \%$ & $83.30 \%$ & $80 \%$ & $87.50 \%$ \\
\hline 7 & $\begin{array}{c}\text { Identification } \\
\text { point }\end{array}$ & $>41.5$ & $<30$ & $>39.5$ & $<30$ \\
\hline 8 & $\begin{array}{c}\% \text { of identified } \\
\text { bones }\end{array}$ & 13 & 33 & 29 & 40 \\
\hline 9 & $\begin{array}{c}\text { Calculated range } \\
\text { (Mean+/-3SD) }\end{array}$ & $24.9-49.5$ & $20.5-40.8$ & $24.5-49.6$ & $20.4-40.2$ \\
\hline 10 & $\begin{array}{c}\text { Demarking Point } \\
\text { (D.P) }\end{array}$ & $>40.8$ & $<24.9$ & $>40.2$ & $<24.5$ \\
\hline 11 & $\begin{array}{c}\% \text { of clavicles } \\
\text { beyond D.P }\end{array}$ & 20.6 & 0 & 21.2 & 0 \\
\hline
\end{tabular}

Fig. 1: Method of marking mid shaft circumference.

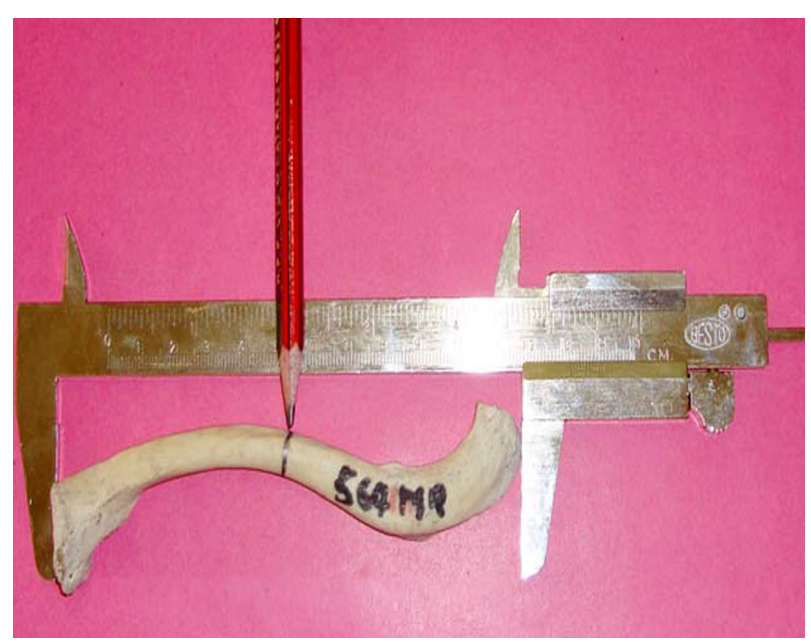


Fig. 2: Measuring mid shaft circumference with the strip of graph paper.

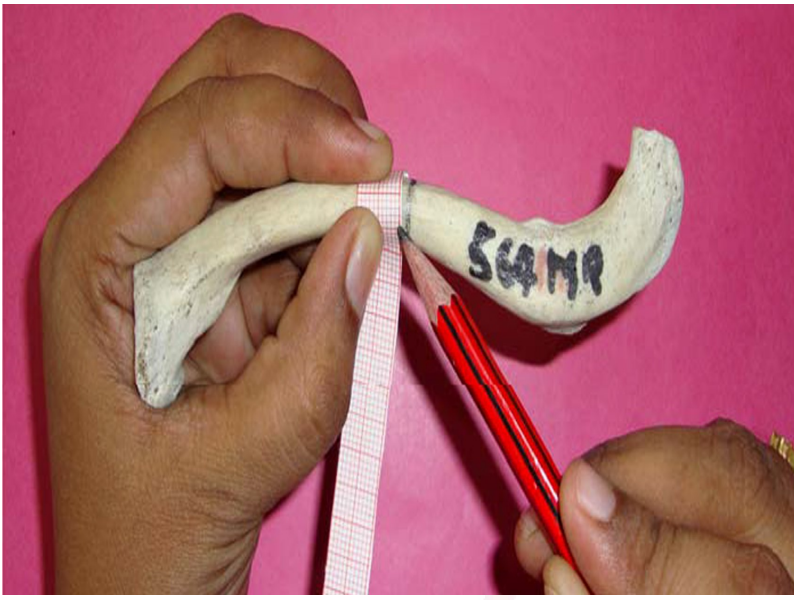

Graph 1: Comparison of mean mid-shaft circumference (in $\mathrm{mm}$ ) of male and female clavicles.

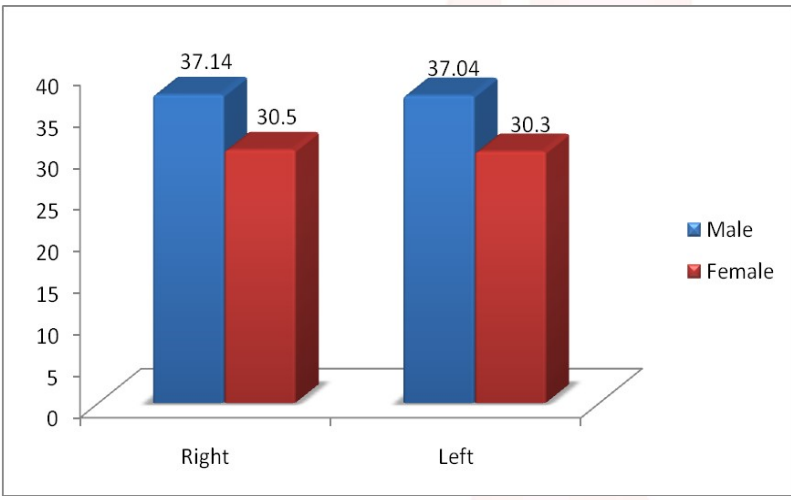

Right clavicle: In the present study, the mid-shaft circumference of right side male clavicles ranges from 30 to $46 \mathrm{~mm}$ with a mean of $37.14 \mathrm{~mm}$ and SD of \pm 4.10 , while that of female clavicles ranges from 25.5 to $41.5 \mathrm{~mm}$ with a mean of $30.50 \mathrm{~mm}$ and SD of \pm 3 .3. Thus the mean mid-shaft circumference of male right clavicle is more than that of female right clavicle with a difference of $6.64 \mathrm{~mm}$. These differences between mid-shaft circumference of male and female are statistically highly significant for sex differentiation $(p<0.001)$ and probability of prediction of correct sex by mid-shaft circumference of clavicle alone is $77 \%$ for male and 83.30\% for female right clavicles.

The clavicles which don't show any overlaps in their mid-shaft circumference value with that of opposite sex are correctly identified as of particular sex. Accordingly, $13 \%$ of right male clavicles measuring their mid-shaft circumference more than $41.5 \mathrm{~mm}$ are identified as of male, while $33 \%$ of female right side clavicles measuring their mid-shaft circumference less than $30 \mathrm{~mm}$ are identified as of female.
On applying demarking point calculation, calculated range of mid-shaft circumference for right male clavicle is 24.9 to $49.5 \mathrm{~mm}$ and that for right female clavicle is 20.5 to $40.8 \mathrm{~mm}$. The right clavicles having their mid-shaft circumference beyond these demarking points could be sexed accurately.

Left clavicle: The mid-shaft circumference of left male clavicles ranges from 30 to $48 \mathrm{~mm}$ with a mean of $37.04 \mathrm{~mm}$ and SD of \pm 4.2 , while that of female left clavicles ranges from 24.5 to $39.5 \mathrm{~mm}$ with the mean of $30.3 \mathrm{~mm}$ and SD of \pm 3 .3. Thus, mid-shaft circumference of left male clavicle is greater than left female clavicle with a mean difference of $6.74 \mathrm{~mm}$. This difference is statistically significant for sex differentiation $(p<0.001)$. The probable prediction of correct sex of left clavicle by mid-shaft circumference alone is $80 \%$ in case of male and $87.50 \%$ in case of female. The left clavicles measuring their midshaft circumference $>39.5 \mathrm{~mm}$ are identified as male ( $29 \%$ of left male clavicles) and that having their mid-shaft circumference $<30 \mathrm{~mm}$ are identified as female bones (40\% of left female clavicles), i.e. $29 \%$ of male and $40 \%$ of female left sided clavicles don't show any overlapping in their mid-shaft circumference.

Demarking points for Left Clavicle: The calculated range for left male clavicle is 24.5 to $49.6 \mathrm{~mm}$ and that for left female clavicle is $20.4 \mathrm{~mm}$ to $40.2 \mathrm{~mm}$. Thus the demarking point for left clavicle in male is $>40.2 \mathrm{~mm}$ and in females is $<24.5 \mathrm{~mm}$.

\section{DISCUSSION}

The mid-shaft circumference of the clavicle had been calculated in several races by different workers and this is the most popular clavicular parameter used for sex identification. Oliver $G$ [6-12] has provided a table giving finding of various workers in this regard. Presently, Table No.2 shows the comparison of mid-shaft circumference of clavicles as estimated by different authers. It is clear from the table that, mid-shaft circumference in the present study is statistically highly significant $(p<0.001)$ in differentiating the sex of male and female clavicles, which is similar to the studies of Padeyappanavar et al [13], Jit I and Sahni D [9]. However, most other studies have not quoted statistical significance. 
Table 2: Comparison Of Mid-Shaft Circumference Of Male \& Female Clavicles By Different Author.

\begin{tabular}{|c|c|c|c|c|c|c|c|c|c|}
\hline \multirow{2}{*}{ SI. No. } & \multirow{2}{*}{ Year } & \multirow{2}{*}{ Author } & \multirow{2}{*}{ Region } & \multirow{2}{*}{ Side } & \multicolumn{2}{|c|}{ Male } & \multicolumn{2}{|c|}{ Female } & \multirow{2}{*}{ P-value } \\
\hline & & & & & Mean & Range & Mean & Range & \\
\hline \multirow{2}{*}{1} & \multirow{2}{*}{1932} & \multirow{2}{*}{ Terry RJ [5] } & \multirow{2}{*}{ USA Negroes } & $\mathrm{Rt}$ & 40.02 & - & 35.26 & - & \multirow{2}{*}{$<0.001$} \\
\hline & & & & Lt & 38.58 & - & 32.42 & - & \\
\hline \multirow{2}{*}{2} & \multirow{2}{*}{1932} & \multirow{2}{*}{ Terry RJ [5] } & \multirow{2}{*}{ USA whites } & $\mathrm{Rt}$ & 40.02 & - & 35.16 & - & \\
\hline & & & & Lt & 40.06 & - & 38.42 & - & \\
\hline \multirow{2}{*}{3} & \multirow{2}{*}{1951} & \multirow{2}{*}{ Oliver G [6] } & \multirow{2}{*}{ French (France) } & Rt. & 38.4 & - & 31.06 & - & \\
\hline & & & & Lt. & 38.4 & - & 31.6 & - & \\
\hline \multirow{2}{*}{4} & \multirow{2}{*}{1963} & \multirow{2}{*}{ Doengen RV [7] } & \multirow{2}{*}{ Australia } & $\mathrm{Rt}$ & 36.2 & - & 29.5 & - & \multirow{2}{*}{$<0.001$} \\
\hline & & & & Lt & 36.2 & - & 29.5 & - & \\
\hline \multirow{2}{*}{5} & \multirow{2}{*}{1966} & \multirow{2}{*}{ Jit I \& Singh S [8] } & \multirow{2}{*}{ Amritsar Zone } & Rt & 36.17 & $27.11-45.23$ & 29.69 & $24.47-34.91$ & \multirow{2}{*}{$<0.001$} \\
\hline & & & & Lt & 35.7 & $26.22-45.18$ & 29.51 & $23.60-35.42$ & \\
\hline 6 & 1968 & Singh \& \& Gangrade KC [Q] & Varanasi7one & $\mathrm{Rt}$ & 35.09 & $25-28$ & 28.52 & 21-41 & \\
\hline 0 & 1500 & 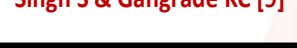 & 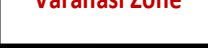 & Lt & 34.64 & $25.12-44.16$ & 28 & $21.32-34.68$ & \\
\hline 7 & 1969 & Singh S [10] & Amorican Nogrape & $\mathrm{Rt}$ & 39.96 & - & 33.06 & - & \\
\hline $\boldsymbol{r}$ & 1005 & Jiाहात $[0]$ & 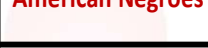 & Lt & 39.08 & - & 32.66 & - & \\
\hline 8 & 1969 & Singh S [10] & American whitec & $\mathrm{Rt}$ & 38.47 & - & 31.61 & - & \\
\hline 0 & 1500 & (III) $5[10]$ & Americantiontes & Lt & 37.61 & - & 30.72 & - & \\
\hline 9 & 1983 & Jit I \& Sahni D [11] & Chandigarh Zone & Rt & 36.2 & $31-45$ & 30.4 & $24.0-35.0$ & $<0.001$ \\
\hline & & & & Lt & 35.9 & $27.8-45$ & 30 & $21.6-38.0$ & \\
\hline 10 & 1992 & Sayeo R ot al [12] & Rangalore zone & Rt & 37 & - & 32 & - & $<0001$ \\
\hline 10 & 1552 & Jayee n el dil [12] & Daligalure zumie & Lt & 37 & - & 35 & - & $<0.001$ \\
\hline 11 & 2009 & Padevanpanavar et al [13] & North \& Interior & Rt & 38.34 & $30.0-54.0$ & 31.76 & $24.0-37.0$ & $<0.001$ \\
\hline & & rauey appaniavai el ail [Dد] & Karnataka & Lt & 37.96 & $28.0-45.0$ & 32.44 & $25.0-39.0$ & -0.001 \\
\hline 12 & 2010 & Present study & North Karnataka & Rt & 37.14 & $30.0-46.0$ & 30.5 & $25.5-41.5$ & $<0.001$ \\
\hline 12 & & & population & Lt & 37 & $30.0-48.0$ & 30.3 & $24.5-39.5$ & \\
\hline
\end{tabular}

Oliver G(1951) [6] states, mean mid-shaft circumference of clavicle in French males as $38.8 \mathrm{~mm}$ and $31.6 \mathrm{~mm}$ in females. In the present study, mid-shaft circumference of right clavicle in male is $(37.14 \mathrm{~mm})$ is comparable with all studies except that with Terry RJ [5] for USA Negroes $(40.02 \mathrm{~mm})$ and USA Whites $(40.02 \mathrm{~mm})$ and Singh S for American Negroes (39.93mm), which are greater comparatively. The mean mid-shaft circumference of right clavicle in females in the present study $(30.5 \mathrm{~mm})$ is also comparable with almost all studies except Terry RJ [5] and Singh S [10]. Similarly on the left side, mean mid-shaft circumference in male $(37.0 \mathrm{~mm})$ and in female $(30.3 \mathrm{~mm})$ of present study is comparable with all the studies except with Terry RJ [5], Singh S [10]. This difference in mid-shaft circumference of clavicles between Indian and Americans is seen because people in the western countries are definitely strong and stout than the Indians.

Sexual difference: It is agreed by most of the previous workers that female clavicle has a smaller circumference than male and this difference is statistically highly significant and varies from 3.7 to $7.8 \mathrm{~mm}$. In the study by Terry $\mathrm{RJ}(1932)$ [5], the circumference of Negro female bone was about $5 \mathrm{~mm}$ shorter than that of Negro male. Oliver G(1951) [6] found the difference to be $6.8 \mathrm{~mm}$ in French bones. Jit and Singh $S(1966)$ [15] found the difference to be $6 \mathrm{~mm}$ $7 \mathrm{~mm}$. In the present study, the difference is about $6.5-7 \mathrm{~mm}$. This shows that, mid-shaft circumference is an extremely useful data by which a fairly large number of clavicles can be sexed without any difficulty. The prediction of sex by mid-shaft circumference alone is $77 \%$ in male, $83.30 \%$ in female right clavicles and $80 \%$ in male, $87.50 \%$ in female left clavicles. These results are similar to results of Jit I and Singh S (1966) [8] and Padeyappanavar et al (2009) [13]. When this measurement is analysed by multivariate analysis along with length, weight and volume will yield still better prediction of sex i.e., $87.2 \%$ in male right, $86.7 \%$ in female right and $82.6 \%$ in male left and $87.5 \%$ female left clavicles.

On applying demarking point for sex determination by mid-shaft circumference, in the present study, $20.6 \%$ of right, and $21.2 \%$ of left 
male but no (0\%) female clavicles could be sexed correctly, as no female bone measures its mid-shaft circumference beyond demarking point. These results are similar to results of Sayee R et al (1992) [12]. But, in study of Jit I and Singh S [8] even female clavicles could be sexed accurately by applying demarking point.

\section{CONCLUSION}

The Mid-shaft Circumference as a parameter of sex determination is statistically significant $(p<0.001)$ in differentiating the sex of the clavicle. This gives better result of than weight of clavicle as weight of the bone varies with age \& health status of the individual. The mean Mid-shaft Circumference of male clavicles was more than that in females. The probability of prediction of sex of clavicles by Mid-shaft Circumference alone is 77 to $87.50 \%$ in both sexes. The prediction of correct sex in clavicle could increase on multivariate analysis of various morph metric parameters like volume, length \& weight of the clavicle.

\section{ACKNOWLEDGEMENTS}

Departments of Anatomy and Forensic Medicine, J.J.M. Medical College, Davangere.
[5]. Tery RJ: The clavicle of American Negro Am J phys Anthropology, 1932; 16 351-380.

[6]. Oliver G: Anthropologic dela clavicule III La clavicule du Francais. Bull Soc Anthrop, 1951;2;121-157.

[7]. Doengen RV: The shoulder girdle and humerus of the Australian Aborigine. Am J Phys Anthropology, 1963;21(4):469-488.

[8]. Jit I, Singh S: The sexing of the adult clavicles. Indian J Med research, 1966 June: 54(6): 551-571.

[9]. Singh S. Gangrade KC: Sexing of adult clavicledemarking points for Varanasi Zone. J Anant Soc India, 1968( b) 17:89-100.

[10]. Singh S: Sexing of Americal clavicles proceedings of the Anatomical society of India J Anat Soc India 1969:18:25.

[11]. Jit I., Sahni D: Sexing the North Indian clavicles. J Anat Soc India,1983;32(2):61-72.

[12]. Sayee R, Janakiram S, Rajangam RK, and Thomas IM.: Clavicle - A metrical study. Journal of Indian Academy of Forensic Sciences, 1992;31(2):24-29.

[13]. Padeyappanavar KV, Kazi AM. Bhusareddy PS. Kulkarni UK: Sexual dimorphism in adult human clavicles of North interior Karnataka. J Karnataka Medicolegal Soc, 2009 June: 18 (1): 3-13.

\section{Conflicts of Interests: None}

\section{REFERENCES}

[1]. Iscan MY: Forensic anthropology of sex and body size. Forensic swenee international 2005;147;107112.

[2]. Knight B ; Knights forensic pathology: the establishment of identity of human remains, $3^{\text {rd }}$ edition. Arnold-hoddler Headline group, London, 2002,; pp 106-117.

[3]. Krofman WM: The human skeleton in Forensic medicine sexing skeletal remains; $2^{\text {nd }}$ edition Charles c. Thomas, publishers- spring-field 1973: 143-151.

[4]. Jit I, Sahni D: Sexing the North Indian clavicles, J Anat soc India, 1983; 32(2): 61-72

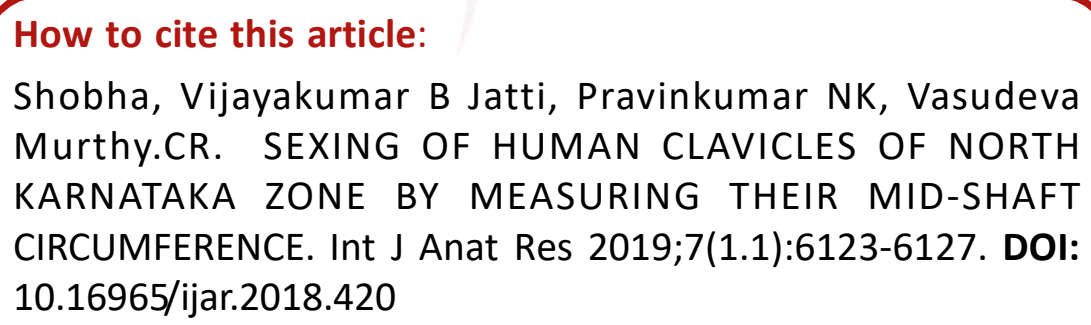

How to cite this article:

Shobha, Vijayakumar B Jatti, Pravinkumar NK, Vasudeva Murthy.CR. SEXING OF HUMAN CLAVICLES OF NORTH KARNATAKA ZONE BY MEASURING THEIR MID-SHAFT CIRCUMFERENCE. Int J Anat Res 2019;7(1.1):6123-6127. DOI: 10.16965/ijar.2018.420 